\title{
Swiping Perennial Famine with Exotic Crops in Pre-Colonial Nigeria: The Case of Esan People in Edo State
}

\author{
Anthony I. Okoduwa \\ Department of History and International Studies, Ambrose Alli University, Ekpoma, Nigeria \\ E-mail: headhisaauekpoma@yahoo.com
}

KEYWORDS Exotic; swipe; perennial; famine

\begin{abstract}
Famine or food shortages are attributed to lack of adequate storage, man made and natural disasters. Famine could also be induced by alteration in environment and population growth. Perennial famine described locally in Esan as ukhumun was a circle of natural events in which surplus usually gave way to scarcity. Famine or ukhumun, lasted from April to September which surplus usually gave way to scarcity. Ukhumun, lasted from April to September when there was little to eat, the latter month marking the beginning of yam harvest. Scarcity during famine was sometimes aggravated when there was draught okae or locust iriso invasion before harvest. During ukhumun or famine, yam the staple crop lost its crumby texture and became rubber-like, difficult to pound into ema or soft yam paste as food for the young and the old. Crop failure or poor harvest therefore merely aggravated the consequences of ukhumun because according to Esan traditions Ukhumun fi bha gbon fibhelin min, aiye miebale meaning "famine was in the land of the living and in that of the spirits and there was no more food to eat". This statement usually prefixed all folk stories in Esan as it emphasized the need for wisdom and caution to sustain the growth of communities. To fill the period of scarcity before harvest, some exotic crops like plantain, maize, cocoyam and fruits were adopted into Esan agriculture especially from the $15^{\text {th }}$ century. There was an increase in the quantity and variety of available food as well as expansion of farm size to accommodate the new.
\end{abstract}

\section{INTRODUCTION}

Esan people were farmers whose main food crop was yam. They live North-East of Benin City in Edo state, and constitute a major subgroup of the Edo language-speaking people in the Mid-Western part of Nigeria. Archaeologists believe that between $2000-3000$ years ago the forestlands of Esan-Benin were inhabited by Stone Age dwellers whose hunting and gathering activities went hand in hand with farming like it is today. The land was favorable for wild yams (Dioscorea spp) and oil palms (Elaesis guineensis). Roland Oliver and Brian M. Fagan explain that wild yams were collected long before they were planted, the transition between gathering and planting being almost undetectable (1975: p. 18). In the same vein, Thurstan Shaw emphasize that the transitional zone was domesticated before population pressure caused people to spread southwards and into the forests where man made clearings provided optimum growing conditions (1980: pp. 34-35).

In yam producing communities like Esan yam was regarded as the "king of crops" or the "staff of life". A shortage of yam caused famine or distress among the people. It was the staple crop for most Nigerians. The domestication of yam has been described as one of the most important events in the agricultural developments in West Africa (Davis: 1967: p. 151). Yam tubers usually have a short life span from the harvest month of September to the bush-clearing month of February hence after the planting month of March, the quantity of yam available for eating is reduced and there is scarcity. By the nature of yam, from the month of planting, tubers grow vines indicating the gradual loss of starch in the tubers. Yam can decay or rot. At such times, farmers sold their excess yam tubers before the planting season was over. Famine or Ukhumu was a perennial problem not because there was no growth of surplus but because the surplus could not be stored over a year.

Farmers maintained close representation of the natural ecosystem so that the original system was little disturbed and high productivity rates maintained at an almost constant level (Agboola, 1979, p. 55). The guinea yam (Dioscorea spp) grew wild with vines that climbed tall trees. Esan people called it Isogo. Ennobled, it no longer competed with other plants for sunlight, nutrients and water resulting in bigger tubers of yam that encouraged growth and development of communities. Other yam species planted during 
the period in Esan included Asukhu (white fibrous tuber) Alebun (white thorny tuber) and Ori (white small tuber). The groups of white yam belong to Dioscorea rotundata. The aerial yam (Dioscorea bulbifera) locally called as Imena was also planted in Esan and other parts of Southern Nigeria.

Agboola has indicated that mixed cropping system was widely practiced among farming communities in Southern Nigeria. The creeping gourd or pumpkin, small vegetables, and yams were all intercropped. In pre-colonial Esan yam was inter-cropped with the indigenous cotton olulu (Gossypium vitifolum), cowpea (Vigna unguiculata) or lima bean varieties known by different local names (ikpakpa, olene, ihiehie, akhikhi), okra ikhiabho (Hibiscus esculentus), pumpkin umekhen (Cucurbita pepo), garden egg, Iruemin (Solamum melongena) and melon ikpekpan or ikpuko (Cucumeropsis edulis). Women planted all these in their husbands' farm as subsidiary crops.

Farmers who displayed a measure of success and skill by the type and number of yam tubers they produced at harvest were respected as Owelle or yam magnate. An Owelle was the farmer that produced consecutively more than what could feed an extended family of about fifty members from one harvest season beyond another making allowance for gift giving and exchange (Oral interview: Ihonre, 2001). His yams were stored in racks that were called oran-eyan. Each rack was made up of between twenty and twenty-two tubers of large or average sized yam. A minimum of twenty racks was locally called Eghodo with an average number of 400 tubers. Ten of such Eghodo formed a line of yams, which was called Ulon-eyan. An Owelle could have ten or more of such lines just like the Diji in Anioma state who produced Ogbe of about 50,000 tubers of yam at harvest. The yam barn was locally called Eru and was previously built in the farms and not at home, a practice that persisted through the $15^{\text {th }}$ century. The barn was a store from where men gave out some tubers to their wives to cook the daily meal of pounded yam.

Thus there was yam enough to serve as food and commodity for trade. However scarcity would result from the short life span of the tubers, precisely six months, beginning from September (harvest month) to February (bush-clearing month). By the nature of the tubers from previous season deteriorate in storage during planting season; in their racks they grow vines indicating gradual loss of the starch in the tubers. Also gradual decay occurs from below the skin into the deeper tissue. Hence, pre-colonial Esan yam farmers sold their excess yam tubers before the planting season was over. Of note however was the introduction of exotic crops into Esan economy at about the same time by migrant farmers from Benin who had been visited by the Portuguese. Interaction with these migrants with new ideas and activities, reduced famine generally. Newly introduced crops provided alternative source of food for the people from one harvest to another.

\section{EXOTIC CROPS}

From the $15^{\text {th }}$ century, new and exotic crops were introduced into Esan land and some other agricultural societies in West Africa like the Igbos, the Urhobos and the Fantes. Portuguese traders whose contact with West Africa began in about 1441 AD brought some of the crops from South East Asia and some from South America. By 1486 a Portuguese factory had been built at Gwatto (Ughoton) in Benin. Ruy de Sequeira reached Benin in 1472. More than a decade later Jao Affonso d'Aveiro presented his credentials at the Court of Benin to Oba Ozolua in 1486(Hodgkins, 1975, p.32 and Blake, 1977, p. 86). In some parts of Africa including Angola Portuguese traders settled and established plantations. Some of them remained in Benin when their ship sailed from the port of Gwatto. Some had relationships with the natives and engaged in planting some crops. But their high death rate became a strong deterrent against their long stay in Benin. According to Barros, a Portuguese who was quoted by J.W. Blake, Benin was a very unhealthy region (1977: p. 85).

The importance of newly introduced crops was that they became alternative sources of food until conditions improved with a new harvest. Farmers cultivated the new crops and spread the crop complex from Benin into the Esan forestlands. Maize (Zea mays) is locally called Oka. Maize, a South American crop from Brazil was introduced to West Africa by the Portuguese in the $16^{\text {th }}$ century. Pre-colonial Esan farmers grew Oka. Usually, they inter-cropped it with yam and much of it was consumed green on the cob as a vegetable. Some were preserved after they 
were left to dry as grain and later consumed as flour, agidi or eko, corn akara or ekala-oka, pap or akamu etc., before the new planting season. Like the varieties of water yam, maize also had four varieties. These were differentiated on the basis of grain size and colour ranging from yellow to red, blue and white. Oka (maize) reduced the impact of famine by making maize foods available. It remains as the most important cereal in the entire Southern Nigeria (Agboola, 1979, p. 85). Although Esan people recognised the hard seeded flint maize as oka-ihiaghen,farmers in the area did not grow it.

Another exotic crop of South and Central American origin was pepper, which the Portuguese spread to Benin by the $17^{\text {th }}$ century (Kowal et.al, 1978, p. 296). However Esan had indigenous pepper before the new arrival, which spread by about 1600AD in Europe as well as through Africa and Asian tropics. Esan pepper or the birds eye red pepper locally called asinafianmen belong to the family of Capsicum frutescens. The Portuguese described it in 1486 $\mathrm{AD}$ when they bought pepper from Benin at the port of Ughoton as pimenta-del rabo or genuine pepper distinct from malagueta, which they also bought from East African markets (Blake, 1977, p. 84). Asin afianmen compared to earlier Portuguese interest in spices and pepper was small, very hot and pungent. The pungency or spicy taste is due to the crystalline substance known as capsaicin $\left(\mathrm{C} 18 \mathrm{H}_{27} \mathrm{NO} 3\right)$, concentrated mainly in the placental region where the seeds are attached to the spongy central portion. The hotter the type of pepper the better, as some forms could have contained from 0.2 to 1.0 percent of capsaicin (Kochhar, 1986, p. 193). Despite this advantage of the asin afianmen over the exotic pepper, it could only thrive during the raining season after which the plant died. Also in periods of drought asin afianmen did not do well just like the indigenous specie of yams. But at such times the exotic pepper of South and Central American origin became the source of fresh pepper. Thus exotic pepper plants thrived with little rains or moisture and fruited through the dry season months including the harmattan period.

Cocoyam another crop of significance in precolonial Esan agriculture, was of two kinds. The first C. esculentum locally called Iyokho was of South East Asian origin. Scholars believe that Iyokho cocoyam, plantain and banana were introduced by Indonesian colonists into East Africa from where they were spread to West Africa and Central Africa. According to Isichei cocoyam, plantain and banana found their way into Africa from South Eastern Asia just as India borrowed bulrush, millet, sorghum the baobab and the kapok tree from Africa (1983, p. 29). It is not known when exactly the Iyokho cocoyam came into Esan agriculture except that it was long in use before the coming of the Portuguese during the $15^{\text {th }}$ century. Like most foreign crops, which were introduced into the indigenous economy, cocoyam maintained a subsidiary position when compared with yam and was planted by women. There were three varieties of Iyokho cocoyam that were planted along with yam in the farms and homesteads before the $15^{\text {th }}$ century. They were the Iyokho-akhatit, Iyokho-odu and Iyokho-omenlo. The three were of different qualities. For example, the Iyokho-akhatiti could be pounded and was firm enough in texture to be eaten as ema or foo-foo. But the Iyokho-odu was usually soft and was only used for ema when yam was added to it. Then the Iyokho-omenlo was loved because it was whiter than the other two but extra-soft in texture. Because of its soft nature it was never eaten as ema or pounded yam but was used for porridge after cooking with palm oil, salt and pepper. Children ate it with relish.

Early European traders introduced the second type of cocoyam into West Africa. Short-distance migrant farmers spread its knowledge as a root crop to Esan in the $15^{\text {th }}$ century. Cocoyam (Xanthosoma sagittifolium) was of tropical American origin and was locally called Ema-ebo meaning European yam. Unlike the Iyokho 2 emaebo produced pods with several small tubers attached to them. The tubers were eaten either roasted or boiled while the pods were stored after harvest for replanting. In situations of all-round yam failure due to locust invasion pest or draught, cocoyam became available as a substitute for yam. Even when left unattended to it produced well and became emergency food in times of hardship. Its broad leaves were used as umbrellas during rainfall and were not easily infected or eaten by pests hence they were used as wrappers to preserve nuts including cola. Moreover, because of its broad leaves cocoyam was hardly suppressed by weeds Asiatic and it could remain in the soil without being harvested from one season to another with no rot of tubers (Oral interview: Anslem Ighenegbale, 2004). In 
the period of Ukhumu, cocoyam ema_ebo became a substitute for yam. Harvested cocoyam was usually kept in a dry corner of the compound with ashes sprinkled on it from time to time usually every two weeks to prevent pests and rodents from destroying them.

An exotic crop that spread from Asia was plantain (Musa paradisiaca). It helped to expand the agricultural economy in pre-colonial Esan. It is not known when exactly plantain was first grown in Esan although scholars suggest that plantain and banana were Asiatic crops that diffused from East Africa westward and across Central Africa to West Africa (Kochhar, 1986, p. 193). Like other Asiatic crops including water yam that were introduced into Esan by migrating farmers in the $15^{\text {th }}$ and $16^{\text {th }}$ centuries, plantain locally called Oghede was regarded as a subsidiary crop. Oghede was not a famine crop since the plant never fruited during the famine period known as Ukhumu. Instead, it produced during the season of yam harvest. Communities in the forest zone including the Igbo, Yoruba and the Ika have the adage that plantain does not allow its use as food during the months of famine. Esan people put it, as Oghede_oi_be Omonoria_bhi okae meaning that plantain does not produce food to grow children during the dry season. However, plantain with the least tending grows in homesteads and on rubbish mounds. Plantain is one of the major food crops in Southern Nigeria today despite its seasonal nature. The fact that when plantain plants reached maturity they no longer need any tending assured its continuity in the agricultural economy of the people. Moreover, plantain was available as food even when there was a lean harvest of yams in pre-colonial Esan. Plantain was usually cooked or roasted on fire and eaten with palm oil and salt. Sometimes the ripe plantain was pounded together with some unripe ones to make a pudding and cooked with some palm oil and salt as food.

Cassava (Manihot) locally called Oho is said to be of South American origin and was introduced into West Africa by the Portuguese. Its culture spread from Fernando Po to Warri when emancipated slaves from Brazil, the West Indies and Sierra Leone returned to parts of Southern Nigeria by the 1850'. The returnees played an important role in stimulating its acceptance as an edible root especially as they knew the methods of processing the crop into food and how to get rid of the cyanic acid that it contained. They spread their knowledge to the people of Lagos, Badagry, Abeokuta and Ijebu. They also popularised cassava as food through their own consumption of it. Soon other people around emulated them especially in the demand for grated and processed cassava known as garri (Oral interview: Michael Oyedo, 2004).

Various factors including social, economic, physical and psychological played their parts in the spread of cassava into the interior. That it was an acceptable food among urban folks and a profitable crop to grow in the hinterland helped to remove the barriers towards its acceptance as an agricultural crop. The increasing drift of people between the coast and the interior helped to spread the cassava culture. Cassava was also relatively easy to propagate while labour requirements for planting and weeding the farm was low compared to yam.

Early knowledge of cassava in Esan came from ex-slaves who returned after the British abolition of 1807. Mr. Agbile was one. Another was Mr. Scott who came back from America and asked for a place to settle in Ubiaja-Esan (Okoduwa, 1983, p. 38). He raised a type of cassava that was locally described as Oриериe meaning "soft soft". The opuepue was the red skin type of cassava, which when boiled and pounded into ema was like the yam paste or foofoo. Even then, fear of the lethal acid content of cassava, which claimed lives of those who ate it without adequate knowledge of how to prepare the various types, prevented cassava to be a popular crop in Esan. It was called a famine crop and was only used when there was a lean harvest of yam (Aveling et al., 1925-1926, p. 128). At such times, ориерие cassava was boiled and used in place of yam for ema. By 1960, Okojie commented "Garri, fried grated cassava, introduced into Ishan round about 1925, has almost ousted yams as Ishan's staple food by virtue of its cheapness and ease of conversion into food (Okojie, 1960, p.28).

The $15^{\text {th }}$ and $16^{\text {th }}$ centuries marked a watershed in the spread of exotic crops in pre-colonial Esan. From then exotic crops were dispersed among farmers and communities not only in Esan but all over West Africa. Crops like pineapple locally called Edin_ebo, avocado pear called Olumu_ebo, and banana known among the Etsako people as Oghede_ebo and in Esan as Ijemeca, a corruption from the word Jamaica were widely spread and 
planted along with indigenous crops. Usually, exotic crops were suffixed with the word ' $e b o$ ' meaning European. For example, pineapple was locally called edin-ebo comparing it to a bunch of the oil palm fruit locally called edin. Thus exotic crops had descriptive names rather than indigenous names. Pineapple, (Ananas comosus) had its origin from the Americas and was spread to West Africa by the Portuguese (Kochhar, 1986, p.198). Although the planting of pineapple did not attract commercial status until recent times, it however increased the variety of fruits that were available in the area, thereby enhancing the food supply and variety in Esan.

By the $19^{\text {th }}$ century, more foreign crops including tomato, paw-paw, guava and oranges were added to the variety of exotic crops, which were planted in pre-colonial Esan. Compared to earlier ones these late arrivals were introduced by European missionaries and adventurers to West Africa, hence their local names were derived as a corruption of their foreign names e.g. tomatoes was locally called Itamatosi, guava as gova, etc.

Tomato (Lycopersicon esculentum) was a crop of South American origin, which arrived West Africa in the late $19^{\text {th }}$ century. Early missionaries made mission gardens as model farms where the new crops were planted and the native staff learnt how to eat and plant them too. In Esan Rev. Father Corbeau, the first European resident was an ardent missionary and farmer who raised crops including tomato in his mission garden at Ubiaja and in Okpujie in Uromi where he supervised the building of his house and a church partly from Ubiaja and from his temporary site or quarters at Agbanmheni, Uromi (Okosun, N.D, p. 23). The native staff spread knowledge of tomato planting and use to their villages from where the skill diffused into other areas. Thus tomato gradually gained acceptance as a common crop and was produced by farmers. The ripe fruits were usually sliced or grated into red oil, pepper and salt and fried to eat boiled yam. Because of the sizzling noise of grated tomato in hot red oil the stew was locally called 'fry'. By the end of colonial rule in 1960, tomato and rice remained a delicacy in the rural areas. Today, tomato is one of the most important vegetables in Southern Nigeria.

Other crops, which were also introduced by early Europeans and missionaries included grapefruits (Citrus paradisi), tangerine (Citrus reticulate) cocoa (Theobroma cacao) and rubber. These crops were introduced into Esan in the $20^{\text {th }}$ century. From the $15^{\text {th }}$ century, Esan farmers like their neighbours in Anioma and Benin adapted many exotic crops into the indigenous agricultural system because such crops complemented local needs and provided cushion in times of famine.

\section{CONCLUSION}

Although exotic crops were regarded as secondary or subsidiary to indigenous crops like yam, they were useful in bridging the gap between planting and harvesting when there was famine. Ukhumu was usually aggravated by draught Okae or locust iriso invasion that destroys many plants. The South American and South East Asian crops that were introduced into Esan from the Portuguese and other Europeans who reached Benin and Esan were usually resilient to adverse weather conditions and as such plantain, wateryam, coco-yam, and several others were available when there was a lean harvest of the indigenous crops especially yam. Also most of the exotic crops that were accepted for cultivation by Esan farmers in the period were capable of vegetative reproduction. This factor enhanced the continuity of such crops in Esan.

\section{REFERENCES}

Agboola S.A. 1979. An Agricultural Atlas of Nigeria. London: Oxford University Press.

Aveling H.G., Hook R.J., Natt J.G and Williams J.A. 1926. Intelligence Reports, Ishan I. CSO/26/I.D 229/A, Ibadan-Nigeria: National Archives.

Blake J.W. 1977. West Africa, Quest For God and Gold 1454-1578. London: Curzon Press.

Falola Toyin. 1984. The Political Economy of a precolonial African State: Ibadan 1830-1900, IbadanNigeria: African Press Ltd.

Hodgkins Thomas 1975. Nigerian Perspectives, A Historical Anthology. London: Oxford University Press.

Isichei E. 1983. A History of Nigeria. London: Longmann publishers.

Kochhar S.L.1986. Tropical Crops. A textbook of economic botany. India: Macmillan Publishers.

Kowal J.M.and A.H. Kassami. 1978. Agricultural Ecology of the Savannah: A Study of West Africa. London: Oxford University Press.

Oral interview with Chief Anslem Ighenegbale 2001, Udo-Esan.

Oral interview with Joel Ihonre,2001, Ekpoma-Esan.

Oral interview, with Michael Oyedo, 2001, Olinlin-Uzea, Esan. 
Okoduwa A.I. "British Administration in Esan 19001960", B.A Long Essay 1983, Dept. of History, Calabar-Nigeria: University of Calabar.

Okojie C.G. 1960. Ishan Native Laws and Customs. LagosNigeria: John Okwessa publishers.

Okosun A.M. n.d. Garden of Eden; Catholicism in Uromi, n.d. Benin City-Nigeria: Reky.Printers.
Oliver Davis, 1967. West Africa before the Europeans. London: Methuen publishers.

Roland Oliver and Brian M. Fagan, 1975. Africa in the Iron Age. London: Cambridge University press.

Shaw Thurstan. 1980. "Prehistory", in O. Ikime (ed.), Groundwork of Nigerian History. Ibadan-Nigeria: Heinemann Publishers. 